Article

\title{
Ciguatoxins and Maitotoxins in Extracts of Sixteen Gambierdiscus Isolates and One Fukuyoa Isolate from the South Pacific and Their Toxicity to Mice by Intraperitoneal and Oral Administration
}

\author{
Rex Munday ${ }^{1}$, Sam Murray ${ }^{2, *}$, Lesley L. Rhodes ${ }^{2}$, Michaela E. Larsson ${ }^{3}$ and D. Tim Harwood ${ }^{2}$ \\ 1 AgResearch, Ruakura Research Centre, Private Bag 3240, Hamilton 3214, New Zealand; \\ rex.munday@agresearch.co.nz \\ 2 Cawthron Institute, Halifax Street Campus, Private Bag 2, Nelson 7042, New Zealand; \\ lesley.rhodes@cawthron.org.nz (L.L.R.); Tim.Harwood@cawthron.org.nz (D.T.H.) \\ 3 Climate Change Cluster, School of Life Sciences, University of Technology Sydney, P.O. Box 123, Broadway, \\ Sydney 2007, NSW, Australia; Michaela.E.Larsson@student.uts.edu.au \\ * Correspondence: Sam.murray@cawthron.org.nz; Tel.: +64-3548-2319
}

Received: 29 May 2017; Accepted: 27 June 2017; Published: 30 June 2017

\begin{abstract}
Ciguatoxins (CTXs), and possibly maitotoxins (MTXs), are responsible for Ciguatera Fish Poisoning, an important health problem for consumers of reef fish (such as inhabitants of islands in the South Pacific Ocean). The habitational range of the Gambierdiscus species is expanding, and new species are being discovered. In order to provide information on the potential health risk of the Gambierdiscus species, and one Fukuyoa species (found in the Cook Islands, the Kermadec Islands, mainland New Zealand, and New South Wales, Australia), 17 microalgae isolates were collected from these areas. Unialgal cultures were grown and extracts of the culture isolates were analysed for CTXs and MTXs by liquid chromatography tandem mass spectrometry (LC-MS/MS), and their toxicity to mice was determined by intraperitoneal and oral administration. An isolate of G. carpenteri contained neither CTXs nor MTXs, while 15 other isolates (including G. australes, G. cheloniae, G. pacificus, G. honu, and F. paulensis) contained only MTX-1 and/or MTX-3. An isolate of G. polynesiensis contained both CTXs and MTX-3. All the extracts were toxic to mice by intraperitoneal injection, but those containing only MTX-1 and/or -3 were much less toxic by oral administration. The extract of G. polynesiensis was highly toxic by both routes of administration.
\end{abstract}

Keywords: ciguatera fish poisoning; Gambierdiscus; ciguatoxins; maitotoxins; toxicity to mice

\section{Introduction}

Ciguatera Fish Poisoning (CFP) is a global food safety issue caused by the consumption of reef fish contaminated with ciguatoxins (CTXs) and possibly maitotoxins (MTXs) [1,2]. Between 25,000 and 50,000 people from South Pacific communities are affected annually, and epidemiological studies indicate that $\leq 20 \%$ of actual cases are reported (www.ciguatera-online.com). The poisoning is considered a neglected disease world-wide, and there is an urgent need for research to improve monitoring of CTXs to aid the understanding and management of the syndrome. To stimulate research activities into CFP, the Intergovernmental Oceanographic Commission of UNESCO's Harmful Algal Bloom programme (http://hab.iocunesco.org) has developed an 'IOC/IPHAB Global Ciguatera Strategy 2015-2019'.

CFP occurs throughout the tropical and sub-tropical waters of the South Pacific Ocean and affects many of the indigenous populations that inhabit the islands, both populated and remote [3-6]. It is caused by CTX- and MTX- producing dinoflagellate species in the genus Gambierdiscus Adachi 
\& Fukuyo and Fukuyoa Gómez, Qiu, Lopes \& Lin [7]. The perception is that CTXs linked to CFP are bio-magnified and bio-transformed up the food chain, to the higher trophic omnivorous and carnivorous reef fish species often targeted by both commercial and recreational fishers $[8,9]$. This bio-transformation converts the algal-derived toxins into more toxic forms, creating a complex suite of compounds. CTXs are large, extremely lipophilic, ladder-shaped polyether marine toxins that are odourless, tasteless, heat stable, lipid soluble, and resistant to gastric degradation. While MTX is among the most potent marine toxins identified to date, it has been primarily found in the digestive tract of fish rather than bio-accumulating in the flesh. The oral potency is much lower than the i.p. toxicity, which suggests it may only play a role in CFP cases if these tissues are consumed. Intoxication manifests as a wide array of gastrointestinal, neurological, and/or cardiovascular symptoms. While fatalities are uncommon, there is no reliable treatment or antidote, and therefore chronic illness cases provide most of the data for epidemiological assessments [10].

Gambierdiscus and Fukuyoa may be found living epiphytically on macroalgae and corals, or attached to the benthos, and are globally distributed in tropical to warm-temperate environments $[11,12]$. Global warming has resulted in an expansion of the sub-tropical latitudes and subsequently the habitable regions for Gambierdiscus and Fukuyoa are expanding [13]. These now include the New South Wales (NSW) coastline, Australia [14], and the northern tip of New Zealand, although Gambierdiscus/Fukuyoa species isolated in New Zealand so far have been non-toxic $[15,16]$. If climate change and the associated warming seas continue to rise, the habitable range may encompass more of both New Zealand's and Australia's coastline, with potentially negative impacts. The Pacific region is being impacted by increasing temperatures, largely caused by carbon emissions generated in the northern hemisphere; low lying atolls are being particularly hard hit. The temperature trends are well documented in a New South Wales Government (Australia) release (http:/ / climatechange.environment.nsw.gov.au/ About-climate-change-in-NSW /Evidence-ofclimate-change/Observed-Australian-climate-change), and a New Zealand government report [17].

In order to provide information on the risk that Gambierdiscus (and Fukuyoa) species pose to consumers of potentially contaminated reef fish, microalgae isolates have been collected from the Cook Islands, Kermadec Islands, New Zealand, and New South Wales, Australia (Table 1), and their toxicity assessed. The assessment includes the newly described species, G. cheloniae [18] and G. honu [19] (both of which are maintained in the Cawthron Institute Culture Collection of Micro-algae (CICCM)). These organisms have been cultured; extracts of the cultures have been analysed for CTXs and MTX-1 and -3 , and they have been examined for acute toxic effects in mice.

\section{Results}

\subsection{Chemical Analysis}

The concentration of CTXs, and relative concentrations of MTX-1 and MTX-3 in the extracts (as determined by LC-MS/MS), are shown in Table 1. MTX-1 quantitation was performed using in-house reference material and the MTX-3 relative peak area was integrated from a single LC-MS/MS run. Variation may be observed upon re-test, as a result of the inherent variability associated with instrument sensitivity.

\subsection{Toxicology}

The median lethal doses of the extracts by intraperitoneal injection and by gavage are shown in Table 2.

Stretching movements were observed immediately after intraperitoneal injection of solutions of the culture extracts (lasting up to 15 min-most likely due to an irritant effect of the test material). At high doses, the mice became lethargic and hunched, with abdominal breathing. Hypersalivation was observed in mice dosed with the extract of G. polynesiensis (CAWD 212), but not with any of the other extracts. In mice dosed with all the extracts, respiration rates declined, and death occurred 
within $4 \mathrm{~h}$ of dosing. At necropsy, it was observed that the stomach contents of these animals were more fluid than normal, and the large intestine was distended with clear gelatinous material. At lower doses, some mice died at up to $24 \mathrm{~h}$ after dosing, while others became anorexic. Persistent anorexia, with consequent loss of up to $20 \%$ of body weight within 2-3 days of dosing, was seen in some mice. In order to avoid long-term suffering, such animals were killed and necropsied, in accord with the requirements of the Organisation for Economic Co-operation and Development (OECD) Humane Endpoints Guidance Document [20]. For calculation of median lethal doses, such euthanized animals were considered in the same way as animals that died on test, as required by OECD 425 [21]. At lower doses, food consumption gradually increased, reaching normal levels within 3-4 days after dosing. These mice gained weight and their food intake, appearance, and behaviour remained normal until the end of the 14 day observation period, after which they were killed and necropsied.

The stomachs of animals dying after $12 \mathrm{~h}$ or more, and those euthanized after 2 or 3 days, were grossly distended with gas. In some cases, stomach contents were liquid, whereas in others the contents were of normal consistency. The weight of food in the stomach of these animals was similar to that observed in control mice, despite the fact that the test animals had eaten little or no food over a period of days and that they had lost 3-4 g in body weight during this time. Reddish-brown or greenish-brown gelatinous material was present in the duodenum and upper jejunum of the mice, and the whole small intestine was erythematous. The caeca of some animals were enlarged, and filled with pale brown liquid material. The large intestine of some mice was empty, while small hard pellets were present in the large intestine of others. As expected for fasted animals, hepatic and splenic weights were decreased in the anorexic mice. Increased relative caecal and small intestinal weights were recorded in some animals, but the relative weights of other organs were, with few exceptions, within the normal range. No abnormalities were recorded at necropsy in animals that survived to the end of the 14 day observation period.

The symptoms of intoxication following oral administration of the extracts were closely similar to those observed after intraperitoneal injection. Mice became immobile, with abdominal breathing, soon after dosing. Hypersalivation was again observed in animals dosed with the extract of CAWD 212. Death occurred at high doses of the extracts, although the time taken to die was longer than that observed after intraperitoneal injection. Anorexia was again induced after oral administration of the extracts, requiring euthanasia of some animals. The macroscopic changes in the gastrointestinal tract of mice dying or euthanized were the same as those seen after intraperitoneal injection. The appearance and behaviour of mice that recovered and began eating normally remained normal throughout the 14-day observation period. After recovering from initial anorexia, their daily food intake was within the normal range. No abnormalities were observed in these mice at necropsy. 
Table 1. Concentration of CTXs, MTX-1 and MTX-3 in the Gambierdiscus and Fukuyoa extracts, as determined by LC-MS/MS.

\begin{tabular}{|c|c|c|c|c|c|}
\hline Cawthron ID & Organism & Source & Total CTXs (pg/Cell) ${ }^{a}$ & MTX-1 (pg/Cell) & MTX-3 (Peak Area/Cell) ${ }^{b}$ \\
\hline CAWD 213 & G. pacificus & Rarotonga, Cook Islands & ND & ND & 7 \\
\hline CAWD 227 & G. pacificus & Rarotonga, Cook Islands & ND & ND & 18 \\
\hline C14 CI & G. pacificus & Rarotonga, Cook Islands & ND & ND & 18 \\
\hline CAWD 233 & G. honu & Rarotonga, Cook Islands & ND & ND & 5 \\
\hline CAWD 242 & G. honu & N Meyer Is., Kermadec Islands & ND & ND & 5 \\
\hline S 8 xii & G. australes & Rarotonga, Cook Islands & ND & 2.0 & 14 \\
\hline CAWD 149 & G. australes & Rarotonga, Cook Islands & ND & 2.3 & 21 \\
\hline S4G & G. australes & Rarotonga, Cook Islands & ND & 2.4 & 18 \\
\hline S5(6)GC2a & G. australes & Rarotonga, Cook Islands & ND & 3.5 & 33 \\
\hline CAWD 244 & G. australes & N Meyer Is., Kermadec Islands & ND & 5.9 & 16 \\
\hline S9a & G. australes & Rarotonga, Cook Islands & ND & 5.8 & 27 \\
\hline CAWD 246 & G. australes & Rarotonga, Cook Islands & ND & 8.9 & 32 \\
\hline CAWD 232 & G. cheloniae & Rarotonga, Cook Islands & ND & ND & 0.4 \\
\hline CAWD 236 & G. cheloniae & Rarotonga, Cook Islands & ND & ND & 1 \\
\hline CAWD 238 & F. paulensis & Northland, New Zealand & ND & ND & 1 \\
\hline CAWD $237^{c}$ & G. carpenteri & New South Wales, Australia & ND & ND & ND \\
\hline CAWD 212 & G. polynesiensis & Rarotonga, Cook Islands & 0.44 & ND & 0.3 \\
\hline
\end{tabular}

a Total CTXs represents the sum of the algal CTXs, quantified as part of this study (P-CTX-3B, P-CTX-3C, P-CTX-4A and P-CTX-4B). ${ }^{\mathrm{b}}$ MTX-3 peak area was integrated from a single run. Variation may be observed with inherent fluctuations in instrument sensitivity. ${ }^{c}$ The original code name for CAWD 237 was UTSMER9A3. ND: not detected. NB: All the Gambierdiscus extracts, except the Australian isolate of G. carpenteri (CAWD 237), contained MTX-3. Only extracts of G. australes contained MTX-1 in addition to MTX-3, and only G. polynesiensis (CAWD 212) contained CTXs. 
Table 2. Acute toxicities of the Gambierdiscus and Fukuyoa extracts, by i.p. injection and by gavage.

\begin{tabular}{|c|c|c|c|c|}
\hline Cawthron ID & Organism & Source & LD50 by i.p. Injection (mg/kg) & LD50 by Gavage (mg/kg) \\
\hline CAWD 213 & G. pacificus & Rarotonga, Cook Islands & $0.50(0.35-0.70)$ & $>400 *$ \\
\hline CAWD 227 & G. pacificus & Rarotonga, Cook Islands & $0.40(0.28-0.53)$ & $>400 *$ \\
\hline C14 CI & G. pacificus & Rarotonga, Cook Islands & $0.94(0.79-1.00)$ & $>320 *$ \\
\hline CAWD 233 & G. honu & Rarotonga, Cook Islands & $0.20(0.15-0.24)$ & $79.0(40.7-98.2)$ \\
\hline CAWD 242 & G. honu & N Meyer Is., Kermadec Islands & $0.20(0.07-0.23)$ & $100(74.9-114)$ \\
\hline S 8 xii & G. australes & Rarotonga, Cook Islands & $0.50(0.25-0.87)$ & $26.8(25.1-32.0)$ \\
\hline CAWD 149 & G. australes & Rarotonga, Cook Islands & $0.37(0.32-0.50)$ & $40.0(29.6-47.4)$ \\
\hline S4G & G. australes & Rarotonga, Cook Islands & $0.42(0.40-0.50$ & $33.8(32.0-40.0)$ \\
\hline S5(6)GC2a & G. australes & Rarotonga, Cook Islands & $0.53(0.50-0.63)$ & $50.0(26.1-61.9)$ \\
\hline CAWD 244. & G. australes & N Meyer Is., Kermadec Islands & $0.50(0.35-0.66)$ & $63.0(47.7-89.7$ \\
\hline S9a & G. australes & Rarotonga, Cook Islands & $1.06(1.00-1.26)$ & $84.2(79.0-100)$ \\
\hline CAWD 246 & G. australes & Rarotonga, Cook Islands & $0.20(0.16-0.25)$ & $20.0(16.0-25.3)$ \\
\hline CAWD 232 & G. cheloniae & Rarotonga, Cook Islands & $0.32(0.221-0.426)$ & $118(100-126)$ \\
\hline CAWD 236 & G. cheloniae & Rarotonga, Cook Islands & $1.58(1.11-2.09)$ & $268(251-320)$ \\
\hline CAWD 238 & F. paulensis & Northland, New Zealand & $10.0(9.53-17.9)$ & $>790 *$ \\
\hline CAWD $237^{a}$ & G. carpenteri & New South Wales, Australia & $10.0(5.1-12.4)$ & $>158 *$ \\
\hline CAWD 212 & G. polynesiensis & Rarotonga, Cook Islands & $1.88(1.58-2.00)$ & $3.20(2.55-4.03)$ \\
\hline
\end{tabular}

a The original code name for CAWD 237 was UTSMER9A3. * Insufficient material was available for determining the median lethal doses of these materials. The figures shown are the highest doses administered, none of which were fatal. Figures in brackets indicate $95 \%$ confidence intervals. 


\section{Discussion}

The extracts of all the Gambierdiscus and Fukuyoa species induced anorexia in mice, both by intraperitoneal injection and gavage, and the macroscopic changes observed in the animals at necropsy were confined to the gastrointestinal tract. It is possible that the extracts inhibited the normal passage of food through the gastrointestinal tract. This would be consistent with the observation that significant amounts of food were present in the stomachs of the anorexic mice, even though they had eaten little or no food for up to 3 days. The presence of gas in the stomach of these animals could possibly be due to the fermentation of their stomach contents. Inhibition of intestinal peristalsis would also explain the presence of material in the duodenum and upper jejunum (which are almost empty in normal animals), and the excessive amount of food-derived material in the caeca of some test animals. Similarly, the presence of hard, dry pellets in the large intestine of anorexic mice could reflect an unusually high degree of water absorption from pre-faecal material, due to prolonged residence time in the intestine.

The acute toxicities of all but one of the extracts by gavage were much lower than those by intraperitoneal injection (Table 3). The differences in toxicity were particularly pronounced with extracts of G. pacificus, G. honu, and G. cheloniae, and rather less with extracts of G. australes. Because of the limited amounts of the extracts of the single samples of G. carpenteri and F. paulensis (=G. yasumotoi), only a limited amount of testing was possible. No effects were seen after oral administration of these extracts at 16 or 63 times the lethal dose by intraperitoneal injection, and it is likely that the ratios between the two parameters are considerably higher than this. The relative toxicity of G. polynesiensis (CAWD 212) was very different to that of the other extracts, being only 1.7 times less toxic by gavage than by intraperitoneal injection. This observation is consistent with the unique presence of ciguatoxins in this extract. Since the initial publication regarding the production of CTXs by CAWD 212 [22], the respective profile and concentration of CTXs per cell has changed significantly. However, as has been presented in this manuscript, the overall toxicity of the algal extract remains high. This suggests that other compounds also contribute to the observed toxicity of the extract. The exact cause for the profile change has yet to be determined; however, publications documenting the effect of epiphytic allopathic bacteria on the growth and toxin production of Gambierdiscus may provide the starting point $[23,24]$. Studies with purified ciguatoxins have shown that median lethal doses by gavage are similar to those by intraperitoneal injection $[25,26]$. Furthermore, although the extract of G. polynesiensis induced the same gastrointestinal changes as the other extracts, it was the only one to cause hypersalivation, which is a characteristic symptom of intoxication by ciguatoxins [26].

Table 3. Ratios between the $\mathrm{LD}_{50}$ of the extracts, by intraperitoneal injection of mice, and that by gavage.

\begin{tabular}{ccc}
\hline Species & Ratio Gavage/i.p. & Mean Ratio \\
\hline G. pacificus & $>800,>1000,>340$ & $>713$ \\
G. honu & 395,500 & 448 \\
G. australes & $54,108,80,94,126,79,100$ & 92 \\
G. cheloniae & 369,170 & 270 \\
G. carpenteri & $>16$ & - \\
F. paulensis & $>63$ & - \\
G. polynesiensis & 1.7 & - \\
\hline
\end{tabular}

There was no association between levels of MTX-3 and acute toxicity. The extreme example is G. cheloniae CAWD 232, which contained only 0.4 peak area/cell of MTX-3, but was more toxic than G. pacificus CAWD 227, which contained 18 peak area/cells, suggesting that CAWD 232 contains a toxin or toxins other than those quantified in the present study.

In a recent in vitro study [27], extracts of 13 Gambierdiscus strains were examined for the presence of CTXs using a neuroblastoma 2a cytotoxicity test, and for MTXs using an erythrocyte lysis test. The results differed from the results by LC-MS/MS analyses presented in this study, as extracts of 
the G. australis strains analysed by the bioassays suggested low CTXs as well as MTXs. The presence of MTXs was indicated in a strain of G. carpenteri from Hawaii, and MTXs have also been detected in G. carpenteri in strains from Australia, the Cook Islands, and French Polynesia (Dr. Tim Harwood, Cawthron Institute, unpubl. data) (although, analyses carried out in this study showed no MTX-3 in the isolate from New South Wales, Australia). The in vitro assays indicated the highest concentration of CTXs in a strain of G. excentricus. In vivo toxicity studies with extracts of this organism would be of interest.

Because of the likely spread of Gambierdiscus from beyond their present range, it is important to assess which, if any, species are likely to cause adverse effects in humans if taken up by seafood. In this study, we have examined extracts of 17 isolates (from 6 Gambierdiscus and 1 Fukuyoa species) for their acute toxic effects in mice, by intraperitoneal injection and by gavage. All the extracts were of similar toxicity; however, all but one was considerably less toxic by oral administration (the most relevant route of administration in this situation), since this will be the route by which humans will be exposed to the toxins contained in these organisms. The relatively low oral toxicity of extracts of G. pacificus, G. honu, G. cheloniae, G. carpenteri, and F. paulensis suggests that these species may be of less concern than G. polynesiensis, which was highly toxic by oral administration.

All the isolates of G. australes contained MTX-1, but only G. polynesiensis produced ciguatoxins (P-CTX-3B, P-CTX-3C, P-CTX-4A, and P-CTX-4B), with P-CTX-3B representing the dominant analogue (approximately 65\% of Total CTX). All isolates, except G. carpenteri, produced MTX-3. Monitoring for Gambierdiscus species is difficult, due to morphological similarities between most species under the light microscope. Therefore, molecular tools are likely to be the way forward for the differentiation of toxic from non-toxic species in sea water samples, and work continues on understanding and targeting the toxin gene $[7,28]$.

The results of this study suggest that the MTX(s) present in the Gambierdiscus and Fukuyoa species that were examined are of relatively low oral toxicity, and work is in progress to isolate and purify these MTXs in order to facilitate detailed toxicological examination.

In the far north of New Zealand, where Gambierdiscus has been reported, and where the related F. paulensis occurs [5,15], a watching brief will be kept in order to determine whether the risk of ciguatera fish poisoning increases with warming seas.

\section{Materials and Methods}

\subsection{Collection of Samples}

Samples were previously collected from Rarotonga, Cook Islands [18,29], North Meyer Island, Kermadec Islands [5,30], Northland, New Zealand [15], and New South Wales, Australia (Larsson et al., in preparation). Cultures were either maintained in the CICCM or maintained in temperature controlled cabinets at Cawthron Institute, for further research. The growth medium was sea water (UV treated and filtered down to $0.22 \mu \mathrm{m}$, using a Millipore filtration system) and $\mathrm{f} 2$ medium (final f2 conc. 25\%) [31]. The culture conditions were $25^{\circ} \mathrm{C} \pm 2{ }^{\circ} \mathrm{C}$ and $40-70 \mu \mathrm{mol} \mathrm{m}{ }^{-2} \mathrm{~s}^{-1}$ photon irradiance (12:12 $\left.\mathrm{h} \mathrm{L}: \mathrm{D}\right)$.

\subsection{Toxin Analyses}

Gambierdiscus cultures (a total of 5 L per strain; 200-2000 cells per $\mathrm{mL}$ ) were sub-sampled $(500 \mu \mathrm{L})$ for cell quantification under the light microscope, using Utermöhl settling chambers. Cultures were harvested in the stationary growth phase by centrifugation $\left(3200 \times g, 15^{\circ} \mathrm{C}, 15 \mathrm{~min}\right)$, and pellets extracted twice with methanol (manuscript in prep.). Extracts were screened for MTX-1 (LoD $1 \mathrm{ng} / \mathrm{mL}$ ) [32] and a putative MTX analogue, previously described as MTX-3 [33]. As the MTX-1 was non-certified reference material, and the MTX-3 unit was calculated from the total peak area of the extract and cell count (certified standards are not currently available), the results presented are for comparison within this study only. Analysis of selected CTXs was carried out using a quantitative LC-MS/MS method, developed at the Cawthron Institute (manuscript in prep.). 
LC-MS/MS analysis was carried out on a Waters Acquity UPLC i-Class system (Waters, Milford, MA, USA), coupled to a Waters Xevo TQ-S triple quadrupole mass spectrometer with electrospray ionization (Waters, Manchester, UK). Chromatographic separation used a BEH Phenyl column (Waters $1.7 \mu \mathrm{m}$, $100 \times 2.1 \mathrm{~mm}$ column), eluted with ammoniated mobile phases: (A) Milli-Q and (B) acetonitrile. Multiple reaction monitoring (MRM) transitions, quantitative and qualitative, were established for $[\mathrm{M}+\mathrm{H}]+$ ions of the various algal CTXs (CTX-3B; CTX-3C; CTX-4A; CTX-4B), and monitored using reference material provided by Dr. Mireille Chinain, Institut Louis Malardé, Tahiti, French Polynesia, and MTX-1 by Prof. Takeshi Yasumoto, Biochemistry and Food Technology Division, National Research Institute of Fisheries Science, Japan. Data acquisition and processing was performed with TargetLynx software (Waters-Micromass, Manchester, UK). Peak areas were integrated and sample concentrations calculated from linear calibration curves, generated from calibration standards.

\subsection{Toxicology}

The culture pellets were freeze dried and then extracted exhaustively with methanol, using a Potter-Elvehjem homogeniser. After evaporation of the solutions to a small volume at $35^{\circ} \mathrm{C}$, using a rotary evaporator, they were aliquotted into glass vials. The methanol was evaporated under a stream of nitrogen, with the last traces being removed under high vacuum. The extracts were stored at $-20^{\circ} \mathrm{C}$ until use.

The median lethal doses of the test materials by intraperitoneal injection and by gavage were determined according to the principles of OECD Guideline 425 [21], and median lethal doses and confidence limits were calculated by use of the computer program associated with this Guideline. In this protocol, a single mouse is dosed with the material under study, at a level that is estimated to be below the lethal dose. The mouse is then observed for $48 \mathrm{~h}$. If the mouse survives, a higher dose (determined on the basis of the computer programme) is administered, and the observation repeated. This process continues until a mouse dies (or is killed, due to the likelihood of prolonged distress). At this point, the next mouse receives the lower dose that was given to the previous mouse. This procedure is followed until enough death/survival reversals (defined as the situation in which survival is observed at a particular dose, and death is observed at the next dose tested, or vice versa (i.e., death followed by survival)) are given for an estimate of the $\mathrm{LD}_{50}$ to be made, which, again, is indicated by the computer programme. This Guideline not only provides an internationally acceptable estimate of the acute toxicity of a chemical, but also the $95 \%$ confidence limits of this estimate. It should also be noted that this procedure uses far fewer animals than classical methods of $\mathrm{LD}_{50}$ determination; in the present experiments, enough reversals were achieved through the use of between six and nine mice. Samples were dissolved in 1\% Tween 60 in normal saline. For toxicity by intraperitoneal injection, aliquots of this solution, made up to a total volume of $1 \mathrm{~mL}$ with the same solvent, were injected into female Swiss mice, of initial body weight $18-22 \mathrm{~g}$. For toxicity by gavage, aliquots of the extract solutions were made up to $200 \mu \mathrm{L}$ with Tween-saline. Tap water and food (Rat and Mouse Cubes, Speciality Feeds Ltd., Glen Forrest, Australia) were available to the mice, both before and after dosing. The mice were monitored intensively during the day of dosing, and survivors were subsequently examined daily. Body weights and food intakes were recorded each day. The weights of the liver, lungs, spleen, kidneys, heart, stomach, small intestine, caecum, and large intestine of all the mice were recorded at necropsy, and relative organ weights were calculated as a percentage of body weight.

Acknowledgments: Thanks to Janet Adamson and Laura Biessy, Cawthron Institute, for their technical support. This study was funded by the NZ Ministry for Business, Innovation and Employment (Safe NZ Seafood contract No. CAWX1317).

Author Contributions: Rex Munday carried out the toxicity studies, Sam Murray and D. Tim Harwood carried out toxin analyses. Lesley L. Rhodes isolated and cultured the dinoflagellates for the toxin analyses, and Michaela E. Larsson isolated, cultured, and provided G. carpenteri from Australia. Rex Munday, Lesley L. Rhodes, and Sam Murray wrote the paper; all authors contributed to and edited drafts. 
Conflicts of Interest: The authors declare no conflict of interest. The funding sponsors had no role in the design of the study; in the collection, analyses, or interpretation of data; in the writing of the manuscript; or in the decision to publish the results.

\section{References}

1. Vetter, I.; Zimmerman, K.; Lewis, R.J. Ciguatera toxins: pharmacology, toxicology, and detection. In Seafood and Freshwater Toxins: Pharmacology, Physiology, and Detection, 3rd ed.; CRC Press: Boca Raton, FL, USA, 2014; Chapter 32; pp. 925-950.

2. Bagnis, R.; Kuberski, T.; Laugier, S. Clinical observations on 3009 cases of ciguatera (fish poisoning) in the South-Pacific. Am. J. Trop. Med. Hyg. 1979, 28, 1067-1073. [CrossRef] [PubMed]

3. Chinain, M.; Darius, H.T.; Ung, A.; Cruchet, P.; Wang, Z.; Ponton, D.; Laurent, D.; Pauillac, S. Growth and toxin production in the ciguatera-causing dinoflagellate Gambierdiscus polynesiensis (Dinophyceae) in culture. Toxicon 2010, 56, 739-750. [CrossRef] [PubMed]

4. Friedman, M.A.; Fernandez, M.; Backer, L.C.; Dickey, R.W.; Bernstein, J.; Schrank, K.; Kibler, S.; Stephan, W.; Gribble, M.O.; Bienfang, P.; et al. An updated review of ciguatera fish poisoning: Clinical, epidemiological, environmental, and Public Health management. Mar. Drugs 2017, 15, 72. [CrossRef] [PubMed]

5. Rhodes, L.; Smith, K.; Harwood, T.; Selwood, A.; Argyle, P.; Bedford, C.; Munday, R. Gambierdiscus and Ostreopsis from New Zealand, the Kermadec Islands and the Cook Islands and the risk of ciguatera fish poisoning in New Zealand. In Marine and Fresh-Water Harmful Algae, Proceedings of the 16th International Conference on Harmful Algae, Wellington, New Zealand, 27-31 October 2014; Mackenzie, L., Ed.; International Society for the Study of Harmful Algae; Cawthron Institute: Nelson, New Zealand, 2015; pp. 180-183.

6. Rongo, T.; van Woesik, R. Socioeconomic consequences of ciguatera poisoning in Rarotonga, Southern Cook Islands. Harmful Algae 2012, 20, 92-100. [CrossRef]

7. Kohli, G.S.; John, U.; Figueroa, R.I.; Rhodes, L.L.; Harwood, D.T.; Groth, M.; Bolch, C.J.S.; Murray, S.A. Polyketide synthesis genes associated with toxin production in two species of Gambierdiscus (Dinophyceae). BMC Genom. 2015, 16, 410. [CrossRef] [PubMed]

8. Bagnis, R.; Chanteau, S.; Chungue, E.; Hurtel, J.M.; Yasumoto, T.; Inoue, A. Origins of ciguatera fish poisoning: A new dinoflagellate, Gambierdiscus toxicus Adachi and Fukuyo, definitively involved as a causal agent. Toxicon 1980, 18, 199-208. [CrossRef]

9. Munday, R. Toxicology of Seafood Toxins: A Critical Review. In Seafood and Freshwater Toxins: Pharmacology, Physiology, and Detection, 3rd ed.; Botana, L.M., Ed.; CRC Press: Boca Raton, FL, USA, 2014; Chapter 7; pp. 197-290.

10. Friedman, M.A.; Fleming, L.E.; Fernandez, M.; Bienfang, P.; Schrank, K.; Dickey, R.; Bottein, M.Y.; Backer, L.; Ayyar, R.; Weisman, R.; et al. Ciguatera fish poisoning: treatment, prevention and management. Mar. Drugs 2008, 6, 456-479. [CrossRef] [PubMed]

11. Parsons, M.; Aligizaki, A.; Bottein, M.Y.D.; Fraga, S.; Morton, S.; Penna, A.; Rhodes, L. Gambierdiscus and Ostreopsis: Reassessment of the state of knowledge of their taxonomy, geography, ecophysiology and toxicology. Harmful Algae 2012, 14, 107-129. [CrossRef]

12. Hoppenrath, M.; Murray, S.A.; Chomerat, N.; Horiguchi, T. Marine Benthic Dinoflagellates-Unveiling Their World Biodiversity; E. Schweizerbart'sche Verlagsbuchhandlung: Stuttgart, Germany, 2014; p. 276.

13. Llewellyn, L.E. Revisiting the association between sea surface temperature and the epidemiology of fish poisoning in the South Pacific: Reassessing the link between ciguatera and climate change. Toxicon 2010, 56, 691-697. [CrossRef] [PubMed]

14. Kohli, G.S.; Murray, S.A.; Neilan, B.A.; Rhodes, L.L.; Harwood, D.T.; Smith, K.F.; Mayer, L.; Capper, A.; Brett, S.; Hallegraeff, G. High abundance of the potentially maitotoxic dinoflagellate Gambierdiscus carpenteri in temperate waters of New South Wales, Australia. Harmful Algae 2014, 39, 134-145. [CrossRef]

15. Rhodes, L.; Gimenez Papiol, G.; Smith, K.; Harwood, T. Gambierdiscus cf. yasumotoi (Dinophyceae) isolated from New Zealand's sub-tropical northern coastal waters. N. Z. J. Mar. Freshw. Res. 2014, 48, 303-310. [CrossRef]

16. Argyle, P.A.; Harwood, D.T.; Rhodes, L.L.; Champeau, O.; Tremblay, L.A. Toxicity assessment of New Zealand and Pacific dinoflagellates Ostreopsis and Gambierdiscus(Dinophyceae) extracts using bioassays. N. Z. J. Mar. Freshw. Res. 2016, 50, 444-456. [CrossRef] 
17. Ministry for the Environment. Climate Change Projections for New Zealand; Report by the Ministry for the Environment: Wellington, New Zealand, 2016; p. 127.

18. Smith, K.F.; Rhodes, L.; Verma, A.; Curley, B.G.; Harwood, D.T.; Kohli, G.S.; Solomona, D.; Rongo, T.; Munday, R.; Murray, S.A. A new Gambierdiscus species (Dinophyceae) from Rarotonga, Cook Islands: Gambierdiscus cheloniae sp. nov. Harmful Algae 2016, 60, 45-56. [CrossRef] [PubMed]

19. Rhodes, L.; Smith, K.; Verma, A.; Curley, B.; Harwood, T.; Murray, S.; Kohli, G.S.; Solomona, D.; Rongo, T.; Munday, R.; et al. A new species of Gambierdiscus (Dinophyceae) from the south-west Pacific: Gambierdiscus honu sp. nov.. Harmful Algae 2017, 65, 61-70. [CrossRef] [PubMed]

20. OECD. Guidance Document on the Recognition, Assessment and Use of Clinical Signs as Humane Endpoints for Experimental Animals Used in Safety Evaluation. 2000. Available online: http://www.oecd.org/ officialdocuments / publicdisplaydocumentpdf/?cote=ENV/JM/MONO(2000)7\&doclanguage=en (accessed on 20 January 2017).

21. Organization for Economic Co-operation and Development (OECD). OECD Guideline for Testing of Chemicals 425. Acute Oral Toxicity -Up-and-Down-Procedure (UDP); OECD: Paris, France, 2006; Available online: http://www.oecd.org/env/test-no-425-acute-oral-toxicity-up-and-down-procedure9789264071049-en.htm (accessed on 20 January 2017).

22. Rhodes, L.; Harwood, T.; Smith, K.; Argyle, P.; Munday, R. Production of ciguatoxin and maitotoxin by strains of Gambierdiscus australes, G. pacificus and G. polynesiensis (Dinophyceae) isolated from Rarotonga, Cook Islands. Harmful Algae 2014, 39, 185-190. [CrossRef]

23. Sakami, T.; Nakahara, H.; Chinain, M.; Ishida, Y. Effects of epiphytic bacteria on the growth of the toxic dinoflagellate Gambierdiscus toxicus (Dinophyceae). J. Exp. Mar. Biol. Ecol. 1999, 233, 231-246. [CrossRef]

24. Caillaud, A.; Iglesia, P.; Darius, T.; Pauillac, S.; Aligizaki, K.; Fraga, S.; Chinain, M.; Diogene, J. Update on Methodologies Available for Ciguatoxin Determination: Perspectives to Confront the Onset of Ciguatera Fish Poisoning in Europe. Mar. Drugs 2010, 8, 1838-1907. [CrossRef] [PubMed]

25. Lewis, R.J.; Sellin, M.; Poli, M.A.; Norton, R.S.; MacLeod, J.K.; Sheil, M.M. Purification and characterization of ciguatoxins from moray eel (Lycodontis javanicus, Muraenidae). Toxicon 1991, 29, 1115-1127. [CrossRef]

26. Lewis, R.J.; Wong Hoy, A.W.; Sellin, M. Ciguatera and mannitol: In vivo and in vitro assessment in mice. Toxicon 1993, 31, 1039-1050. [CrossRef]

27. Pisapia, F.; Holland, W.C.; Hardison, D.R.; Litaker, R.W.; Fraga, S.; Nishimura, T.; Adachi, M.; Nguyen-Ngoc, L.; Séchet, V.; Amzil, Z.; et al. Toxicity screening of 13 Gambierdiscus strains using neuro-2a and erythrocyte lysis bioassays. Harmful Algae 2017, 63, 173-183. [CrossRef] [PubMed]

28. Vandersea, M.W.; Kibler, S.R.; Holland, W.C.; Tester, P.A.; Schultz, T.F.; Faust, M.A.; Holmes, M.J.; Chinain, M.; Litaker, R.W. Development of semi-quantitative PCR assays for the detection and enumeration of Gambierdiscus species (Gonyaulacales, Dinophyceae). J. Phycol. 2012, 48, 902-915. [CrossRef] [PubMed]

29. Rhodes, L.L.; Smith, K.F.; Munday, R.; Selwood, A.I.; McNabb, P.S.; Holland, P.T.; Bottein, M.-Y. Toxic dinoflagellates (Dinophyceae) from Rarotonga, Cook Islands. Toxicon 2010, 56, 751-758. [CrossRef] [PubMed]

30. Rhodes, L.L.; Smith, K.F.; Verma, A.; Murray, S.; Harwood, D.T.; Trnski, T. The dinoflagellate genera Gambierdiscus and Ostreopsis from sub-tropical Raoul Island and North Meyer Island, Kermadec Islands. N. Z. J. Mar. Freshw. Res. 2017, 1-15. [CrossRef]

31. Guillard, R.R. Culture of phytoplankton for feeding marine invertebrates. In Culture of Marine Invertebrate Animals; Smith, W.H., Chanley, M.H., Eds.; Plenum Press: New York, NY, USA, 1975; pp. $29-60$.

32. Selwood, A.; Rhodes, L.; Smith, K.; Harwood, D.T. Development of two novel UPLC-MS/MS methods for the analysis of maitotoxin from micro-algal cultures. In Marine and Fresh-Water Harmful Algae, Proceedings of the 16th International Conference on Harmful Algae, Wellington, New Zealand, 27-31 October 2014; Mackenzie, L., Ed.; International Society for the Study of Harmful Algae; Cawthron Institute: Nelson, New Zealand, 2015; pp. 66-69.

33. Holmes, M.J.; Lewis, R.J. Purification and characterisation of large and small maitotoxins from cultured Gambierdiscus toxicus. Nat. Toxins 1994, 2, 64-72. [CrossRef] [PubMed]

(C) 2017 by the authors. Licensee MDPI, Basel, Switzerland. This article is an open access article distributed under the terms and conditions of the Creative Commons Attribution (CC BY) license (http:/ / creativecommons.org/licenses/by/4.0/). 